\title{
IMPACT OF AGRICULTURAL DEVELOPMENT ON YOUTH EMPLOYMENT IN ZIMBABWE: THE CASE OF MASVINGO PROVINCE
}

\author{
Clainos Chidoko, Silibaziso Zhou, Researchers \\ Great Zimbabwe University, Masvingo, Zimbabwe \\ E-mail: cchidoko@gmail.com
}

Received October 31, 2012

\begin{abstract}
Zimbabwe is basically endowed in agricultural resources. As a result agricultural activities have a large bearing on developmental issues in the country. Employment is one such economic issue that hinges much on agricultural development. Over the past decade employment levels have reduced as a result of low investment in the country. Masvingo Province has not been spared. This scenario has seen many youths being out of employment as the sector employed less labour. The study found out that economic woes that Zimbabwe experienced over the past half decade have contributed significantly to youth unemployment in agriculture in Masvingo Province as a result of low investment in the sector. The study recommends that heavy investment be put in agriculture and agriculture related projects to enhance employment levels of the Zimbabwean youths in Masvingo province.
\end{abstract}

\section{KEY WORDS}

Agricultural development; Youth employment; Investment; Youth labour.

Agriculture forms the backbone of the country accounting for about sixteen to twenty percent of the country's Gross Domestic Product (GDP). It provides an income to almost seventy-five percent of the population. Agriculture also accounts for the majority of informal employment and hosts some twenty-seven percent of the formally employed work force. It contributes about forty percent of the value of merchandise exports, and more than half the value of raw materials to the industrial sector. Domestic trade, transport and many other service activities are also dependent on agriculture.

Life for many indigenous people in Zimbabwe is synonymous with the land. A survey conducted in Masvingo on the effect of land redistribution in 2004 revealed that the land is part of a cultural mix that lies spiritual, material, economic, financial and political aspects of the life of the African people in Zimbabwe. According to the survey, the land distribution programme had three major goals namely resettlement of families that became displaced during the colonial era, development of agriculture and creation of employment. (Masvingo Agricultural Based Community (MABC) Survey November 2004).

The research aims at showing the impact of agricultural development on youth employment in Masvingo Province of Zimbabwe. The research goes through the background information about Masvingo, shows the effects of agricultural reforms youth labour and makes recommendations thereafter.

The province is located in the lowveld of the country where rainfall is very low and at times uncertain. As such the large portion of this province is dry and prone to drought area as it is in region 5 of the country's climatic regions. The government has tried to assist people in this province with irrigation. Examples of such irrigation schemes are the Rozva irrigation Scheme which is located in Bikita district, the Hippo valley estates in Chiredzi and Triangle that use water from Lake Mutirikwi for irrigation purposes. The construction of the Tokwe-Mukosi dam is currently underway. This is a project which is coming on as a realization of the dryness of the province. The harnessed waters shall mainly be used for irrigation purposes. Despite receiving low rainfall, there are a lot of agricultural economic activities in the province that generate employment. The youths and the able bodied are the main supply of labour.

Masvingo is divided into seven administrative districts namely Zaka, Bikita, Chivi, and Masvingo in the center, Gutu in the north and 
Mwenezi and Chiredzi in the south and east respectively. For each rural district there are business centres known as growth points.

Agricultural investment and youth employment. Investment in agriculture in the past decade had gone down, as a result of economic crisis that Zimbabwe experienced in that period. Very few farms were still engaging in meaningful production. Also this was coupled with the problem of aging irrigation equipment and shortage of irrigation waters. The facility was virtually nonexistent. Most youths have been reliant on agricultural employment and related downstream economic activities. As a result the employment levels declined in the province among the youths.

Food Cropping and Cattle ranching in Masvingo Province. According to National Agricultural policy (March 2004), agriculture in Zimbabwe is diversified with 23 types of food crops and cash crops grown. The main food crops include maize, sorghum, pearl millet, millet, groundnuts, soya beans, wheat, sugarcane, barley and sunflower. The main cash crops are tobacco, cotton, tea and horticultural products. Masvingo Province is mainly into dry land farming
Of the main food crops grown in the Masvingo, there is maize, soya beans and on the cash crops there is sugar cane and cotton. There are plenty of sugar beans and onions grown in the irrigation schemes. In the past eighteen years, the seed industry has grown from four companies, consisting of one major hybrid maize seed company, to more than thirty companies, with four major hybrid maize seed companies. The formal seed sector consists of both the public and private sectors. The private sector consists of seed companies and seed traders (wholesalers and stockists) while the public seed sector consist of DR\&SS's Crop Breeding Institute, Seed Services, Plant Protection Research Institute (PPRJ). Other institutions involved in crop research and development are University of Zimbabwe ICRISAT, CIMMYT and other international agricultural research centers. (National Agricultural Policy 2004.2005: First Draft: March 2004)

There are a number of agricultural economic activities that create youth employment in the province, as shown in the table below.

Table 1 - Summary of the agricultural economic activities in Masvingo Province

\begin{tabular}{|c|c|c|c|}
\hline Products & Location & Markets & Employment \\
\hline Sugar cane & $\begin{array}{l}\text { Hippo Valley, Triangle and Mkwasine Es- } \\
\text { tates in Chiredzi and Mwenezi Districts }\end{array}$ & $\begin{array}{c}\text { Local, } \\
\text { Namibia }\end{array}$ & Large scale \\
\hline $\begin{array}{l}\text { Maize, groundnuts, cotton, sorghum, } \\
\text { sunflower, pumpkins, millet }\end{array}$ & Zaka,Chiredzi & Local & Family level \\
\hline Poultry & Zaka & Local & $\begin{array}{l}\text { Village levels (co- } \\
\text { operatives) }\end{array}$ \\
\hline Cattle ranching-Beef & Chivi,Mwenezi & Local & Family level \\
\hline
\end{tabular}

Source: Masvingo urban lime site 2012

Effects of Agricultural Development on Youth Employment in Masvingo.

Agricultural Activities in Masvingo Urban. According to the Masvingo Urban lime site 2012, the livelihood activities for most households in low income suburbs are centered on vending and petty trade. Fruit and vegetable trade and firewood sales are the key income generating activities. Urban agriculture is practiced by most households though the size of the land available for agriculture is very small. Urban agriculture is practiced on the open spaces reserved for other developments by the City Council and along the banks of the stream that passes close to Mucheke and Rujeko suburbs.
Some households have been able to secure some relatively bigger pieces of land on the outskirts of the City. Nearby farms and small plots also provide opportunities for poor households that sell their labor to earn food and income mainly during the summer season. Masvingo town has a small industry base and most of the people that are formally employed work for the government and other service organizations. Masvingo used to have one of the biggest cattle abattoirs in Zimbabwe, and which used to be a source of employment for most residents, but the abattoir has not been fully operational over the past 10 years. Poor and low investment in agriculture over the past decade have impacted much 
on the development of the sector and as a result agricultural activities have dwindled affecting employment of youths in agriculture.

Effects of Agriculture on Education and Employment. The resettlement and agricultural reforms affected Masvingo province, like most areas in Zimbabwe in many ways. The Government during the early years of independence procured the few farms available in the province like Gunikuni, Ngomahuru and Tokwane-Ngundu. Successful small-scale farming communities were established focusing on maize, cotton, Soya beans, beans and livestock production. The biggest problem with these schemes was water and in cases where irrigation schemes were established, the schemes were not managed well. (MABC Survey November 2004).

According to the survey agricultural education was facing many challenges, arising from the changes in the agricultural structure, the increase in the number of farmers requiring farming knowledge, skills, attitude change, technical advice and information against limiting capacity in terms of numbers, geographical distribution or location of agricultural colleges, student enrolment capacities, the numbers of experienced trainers, training equipment, materials and structure of courses offered and exit qualifications. The survey revealed that at full capacities, public agricultural colleges have a potential to produce at least 535 diploma graduates every year. However, due to resource limitations, they had been operating at an average of 350 graduates per year. Training materials and equipment were limited while experienced trainers and education administrators did not receive due recognition.(First Draft, National Agricultural Policy 2004-2005: March 2004).

The changes in the structure of the agriculture sector as a result of the land reform programme had far reaching implications on the agricultural employment of youths in the province. Agricultural education system employed a multitude of young and old agriculturists and farmers. These people require knowledge, skills and attitude orientation for dealing with the dynamic and complex demands of commercial farming, agro-business situations and a good service delivery within the agrarian reform context. The country had seen a massive increase in the number of universities to the extent where each province has at least one. Fortunately for Masvingo there are two universities the Great Zim- babwe University (state owned) and the Reformed Church University(privately owned). The introduction of the faculties of agriculture at the two institutions will go a long way in employing researchers and trainers in agricultural systems.

Food Processing. Although the agricultural reforms have seen an increase in employment in the food production, less has been scored in the area of food processing that add value to the food produced. The Masvingo Polytechnic through its Chemical Engineering Department can be used to come up with several food processing techniques that must be disseminated by the institution to the relevant communities in Masvingo Province. Collaboration between the institution and the province is therefore necessary.

Policy Recommendations. Masvingo Province has witnessed challenges of youth unemployment in agriculture as a result of low investment in the sector. This has been a consequence of the economic crisis that Zimbabwe had gone through during the past decade. The resultant effect was low youth employment. Agricultural reforms and developments have seen a great improvement in the employment of young farmers, researchers and trainers. The universities and technical colleges in the province if fully utilized can take the province to greater steps in terms of food processing and dissemination of knowledge. The research recommends that heavy investment in agriculture can harness the rich youth labour in the province for the good of the sector and economy as a whole. Irrigation facilities have to be put up to complement the efforts from other quarters such as private initiatives and nongovernmental organizations. Institutions in the province such as Masvingo Polytechnic, faculties of Agriculture at Great Zimbabwe and Reformed Church Universities and Agricultural training colleges can be used to come up with several initiatives in agricultural development, food processing techniques and skills training that must be disseminated by to the relevant communities in Masvingo Province. Collaboration between and among the institutions and the province is therefore necessary. This will curb the high unemployment levels as a result of a well developed agricultural system in the province. 


\section{REFERENCES}

Baffes J (2003); Agricultural Support in OECD Countries: An Explanatory Note.

Benson G.A., Marchant M. and Rosson P. (1998), U.S Agriculture and International Trade, Southern Extension International Trade Task Force.

Bird K. \& Prowse M. (2008). Vulnerability, poverty and coping in Zimbabwe. United Nations University. UNU-WIDER Research Paper 2008/41.

Cornia, G. (1985) Farm size, land yields and the agriculture production function, world development, 13/4 esp pp513-525

Drinkwater M. (1991) The State and Agrarian Change in Zimbabwe's Communal Areas, Macmillan Academic: London

Fan S., Zhang X., \& Rao N. (2004). Public expenditure, growth, and poverty reduction in rural Uganda. Development Strategy and Governance Division Discussion.

Fan S., Hazell P. \& Thorat S. (1999) Linkages Between Government Spending, Growth and Poverty in Rural India. Research Report 110. Washington, DC: IFPRI.
Fan S. \& Johnson M. \& Saurkar A. \& Makombe T. (2008). Investing in African agriculture to halve poverty by 2015 . IFPRI discussion papers 751, International Food Policy Research Institute (IFPRI).

Fei J. \& Ranis G. (1961). "A theory of economic development." American Economic Review, Vol.51, no. 4, pp. 533-565.

Masvingo Agricultural Based Community (MABC) Survey November 2004.

Mellor, J.W., (1980). The Economics for Agriculture Development. Cornell University Press.

National Agricultural Policy 2004-2025: First Draft: March 2004

Norton G.W., Alwang J. and Masters A.W. (2010); The Economics of Agricultural Development:, World Food Systems and Resource Use, 2nd Edition, Routledge publications. 